\title{
11. Style, Plot, and Character in Tom Yaya Tales from Ku Waru
}

\author{
Alan Rumsey
}

\section{Introduction}

This chapter is about sung stories and associated modes of performance in the $\mathrm{Ku}$ Waru region of the Western Highlands of Papua New Guinea, which are known as tom yaya kange. This region lies within the broader one referred to by Don Niles in chapter 12 of this volume as the "Hagen Area," which also includes Melpa as discussed both by Niles and by Strathern and Stewart in chapter 13. The chapter will open with a brief introduction to the Ku Waru region and its genres of verbal art. I will then turn to tom yaya kange in particular and describe their distinctive features. The linguistic and musical properties of tom yaya kange and their narrative framing are matters that I have treated in detail in other publications (Rumsey 2001, 2005, 2007, 2010) and which I will accordingly deal with in summary form here. I will then turn to a more detailed consideration of two issues that I have not yet treated systematically in print: (1) the question of how to translate tom yaya kange into English, and (2) the full range of plots of the tom yaya kange that I have recorded, what they have in common, and how this relates to their poetic form and modes of performance. Discussion of the latter point will involve comparison with the range of plots that are found among Melpa kang rom to the west, as described by Strathern and Stewart (1997, 2005b, chapter 13 (this volume)) and by Stewart and Strathern (2002). Since 1965 at least, all kang rom have been tales of courtship. Showing that there is also a strong tendency in that direction in the Ku Waru region, I conclude with a discussion of why that should be the case.

\section{The Ku Waru region and its genres of verbal art}

$\mathrm{Ku}$ Waru and Melpa are regional speech varieties within a larger group that also includes Meam, Umbu-Unggu, and Imbonggu as shown on figure 2 in chapter 1. ${ }^{1} \mathrm{Ku}$ Waru and Melpa are about as closely related to each other as, for example,

\footnotetext{
1 This group comprises a regional continuum within which there is no single set of mutually exclusive names for the dialects or "languages," or for the continuum as a whole. In keeping with the current Ethnologue classification (see chapter 1 for details), the name Umbo-Unggu (meaning literally 'indigenous language') is used here for roughly the same dialect range that is also called Kaugel (or, in Melpa, Köwul/Gawigl), after the valley in which it is spoken and the eponymous river that flows through it. Ku Waru is an intermediate variety between Umbo-Unggu (Kaugel) and Meam (Temboka), the latter being more similar to Melpa. Not shown on this map is the so-called Awa (Aua) dialect, which is spoken by a few hundred people in an outlying region of otherwise uninhabited territory to the east of Meam.
} 
Spanish and Italian. People's way of life is similar across the entire Hagen area, especially in the rural parts that comprise most of it. The local economy is still largely a subsistence one, based on the intensive cultivation of sweet potatoes, taro, and a wide range of other crops. Most households nowadays also grow coffee, which is the main source of cash income. This is used largely to pay school fees ${ }^{2}$ - most children attending local schools through grade six-and for non-market-based transactions such as bridewealth, compensation, and ceremonial exchange. Nowadays it is also used to a considerable extent for storebought food, such as rice, packaged noodles, and tinned fish, but sweet potatoes remain the staple food of nearly everyone, especially in the rural districts where the great majority of $\mathrm{Ku}$ Waru people still live.

Across the entire Hagen Area, social life, including residence patterns, marriage, wealth exchange, and warfare is still to a great extent organized in terms of segmentary units called (in Ku Waru) talapi ("tribes," "clans," "sub-clans," etc.), which range in size from a few score of people to over 10,000. The system of wealth exchange among talapi-called moka (in Melpa) or makayl (in $\mathrm{Ku}$ Waru) - has become a textbook case of such systems through the work of Andrew Strathern (e.g., 1971, and refs. therein; cf. Merlan and Rumsey 1991 on makayl). In some parts of the Melpa region, this system has wound down (Stewart and Strathern 2005), ${ }^{3}$ but it is still in operation throughout much of the $\mathrm{Ku}$ Waru region.

Throughout the $\mathrm{Ku}$ Waru region, as elsewhere in the central and western highlands, men and women formerly lived in separate houses, boys sleeping in their mother's until they were about twelve years old, then moving into their father's. This has changed over the past generation or two-partly under the influence of Christian churches, which are active throughout the region-but men and women still do much of their indoor socializing in separate 'men's houses' (lku tapa) and 'women's houses' (ab lku). Many of their working hours are also spent apart in more-or-less gender-specific tasks, men making the new gardens, building the houses, chopping the firewood; women growing and harvesting the sweet potatoes, tending the pigs, cooking the everyday meals, etc. Nowadays, although there are no towns within the Ku Waru region, many people from there, especially young men, travel frequently, usually by "PMVs" (licensed "public motor vehicles") to the provincial capital of Mt. Hagen (which lies within the southwestern reaches of the Melpa region), to bring their coffee and other cash crops to market, purchase trade goods, drink beer when they can afford it, and generally enjoy the buzz that town life is felt to offer.

2 The Papua New Guinea state does not offer free public education; fees are charged at all levels.

3 More recently, with reference to the main Melpa group that Andrew Strathern has worked with over the past forty-five years, he and his collaborator Pamela Stewart (pers. comm., July 2010) say, "We have discovered over the past five years that moka-type exchanges / compensation payments actually continue among the Kawelka, so the point itself has transformed over time." 
Below a certain level of socio-territorial segmentation, marriage is strictly exogamous with respect to talapi, but with no particular relations of prescribed marriage. Finding a wife (or wives) is a demanding task for a young man and his close kin, as it requires them to assemble a bridewealth payment of, roughly, twenty to thirty pigs (more than are raised by most households in five years) and the cash equivalent of about US\$ 2,000-3,000 (K 5,000-6,000, well beyond most families' total annual cash income; formerly this part of the payment often consisted of gold-lipped pearl shells, then equally hard to attain). Given the continuing practice of polygyny, marriageable women are in short supply relative to the number of men looking for them. Though she does not have the only say as to whom she will marry, a young woman who is being courted is usually allowed a final power of veto in the matter, which she can exercise in the almost certain knowledge that other prospective suitors are waiting in the wings. As we shall see below, the challenges this presents to a young man, and what Stewart and Strathern (2002:123) call the "romance of exogamy," provide one of the main subjects of tom yaya kange.

Skilled use of language is highly valued by $\mathrm{Ku}$ Waru and other New Guinea Highland people. There were no inherited political offices in the area and the leadership status of 'big man' (yi nuim; now to some extent correlated with success in electoral politics) is one that men are said to have always achieved in part through their oratorical ability.

Men and women alike are also composers of songs in several different genres (for examples and discussion see Strathern (1974) and Stewart and Strathern (2002)). There are also several recognized genres of story, all performed both by men and women. There is a primary division between kinds of story which in $\mathrm{Ku}$ Waru are called kange and temani (= Melpa kang, teman). As Francesca Merlan (1995) has shown (see also Rumsey 2005), the difference between these types has to do with the kind of relationship which is set up between the world of the narrated events and the here-and-now world from which they are being narrated. In neither genre is the narrated world necessarily presented as "factual," but the world of temani, even if only by default, is presented in ways that invite the audience to imagine it as continuous with the here-and-now, while that of kange is presented as very different from the here-and-now, but using what Merlan (ibid.) calls "techniques of verisimilitude" by which the audience is invited to imagine themselves into that world - for example by drawing explicit parallels between the characters and places in the story and familiar ones from the local scene in which he or she is telling it: "Once there were two brothers, just like my sons Don and Pai"; "They came to a little hill, like over there at Ambuk1," etc. These and other generic features of kange will be exemplified by the stories presented below. First, I will turn to the question of what makes them kange of the more specific sort known as tom yaya kange. 


\section{Distinctive features of tom yaya kange}

The features which are common to all performances of tom yaya kange / kang rom that have been analysed so $\mathrm{far}^{4}$ are:

1. Clear division into lines, each ending in an added vowel $e, o$, or $a$

2. Use of formulaic expressions, each comprising one or more whole lines

3. Organization of the lines into repeating two-part melodies, the second part being a pitch-by-pitch variation on the first

4. A strong tendency for each line to comprise an integral syntactic unit

5. Extensive parallelism across lines

In addition to these five features, some but not all tom yaya kange display two others, always in conjunction with each other:

6. Rhythmic organization of each line into a fixed number of beats or feet

7. A strong tendency for each beat except the final one to be associated with a single word.

Features 1, 3, and 6 are discussed and exemplified in detail by Niles in chapter 12. They are further exemplified, along with features 2,5 , and 7 , in text 1,5 which presents in bilingual form the opening lines of a story by one of the most renowned composer/performers of tom yaya kange in the western Nebilyer Valley, Paulus Konts (figure 1). ${ }^{6}$

The text begins with a standard opening line which is frequently used in tom yay a kange. The expression ama 'oh mother!' is a frequently used exclamation in Ku Waru, roughly equivalent to "wow!" in English. This line differs from all the following ones in consisting of only four syllables and in not having a vocable at the end. For this and other reasons discussed below, it is best seen as prefatory to the main flow of the tom yaya kange rather than as a part of it. In terms of rhythmic structure, the main flow of the performance begins with line 2. As can be seen, from then on, almost every line consists of four words plus the line-final vocable. As I have demonstrated elsewhere with instrumental-phonetic evidence (Rumsey 2007), depending on the number syllables in each word, when used in these lines of metrical tom yaya kange they tend to be stretched or contracted in order to make all the words in the line of roughly the same audible duration, which also roughly matches that of the vocable at the end of the line. This and

\footnotetext{
4 These include some thirty performances of twenty-five different tales that my assistants and I have made and transcribed during 1983-2004, totalling approximately 18,000 lines. For further details concerning the way in which these recordings have been made and transcribed, see Rumsey (2001:203-5). I have also heard perhaps another thirty performances during that time, which, as far as I could tell, were consistent with the generalizations offered here.

5 For discussion and evidence regarding feature 4, see Rumsey (2007:258-61).

6 For biographical details and a character sketch of Paulus Konts, see Rumsey (2006b).
} 
other factors discussed below establish a regular rhythm to the line with a fixed number of beats or "feet" - in this case five of them, one filled by each of the four words and one by the vocable.

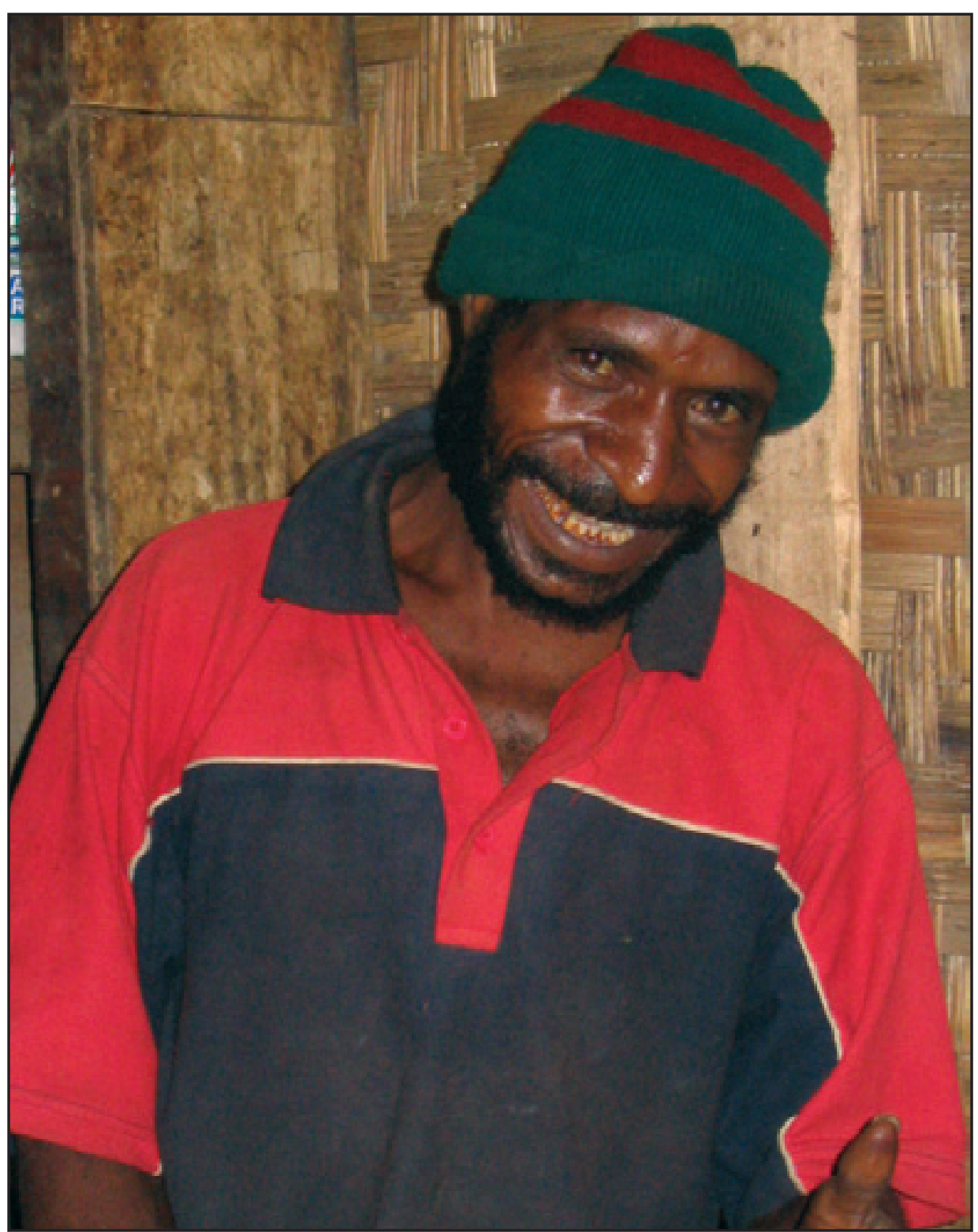

Figure 1. Paulus Konts in Kailge, 2004 (photo by Don Niles).

7 For the occasional lines which do not have enough words or readily separable bound morphemes, one of the words may be stretched over two beats to fill out the line. There are two instances of this in this in text 1 , in line 23 , where mepa is stretched out over two beats, and line 25 , where kela is. 
Sung Tales from the Papua New Guinea Highlands

Text 1. Opening lines from the story of Rosa and Koka as performed by Paulus Konts, 2 March 1997. An audio file of this example can be found in online item 17.

1. ama na na

2. puku to pena purum e

3. puku to lkud urum e

4. olu-ma ngil nyirim e

5. lupal-ma tom turum e

6. nu takan mului nyib a

7. kanab a taka nyiba a

8. kayi nga we kaniyl e

9. mong-ne kubi kel e

10. kubi-ne mong kel e

11. kanab a taka nyiba a

12. kayi nga mon kaniyl e

13. puku to pena pupa e

14. puka topa lkudu urum e

15. madi luyiya tok piring e

16. na ultuk pubu nyirim e

17. ab rota ab nayi e

18. nu nanga kuk wanyayl e

19. lumayia tunjan pui nyirim e

20. puyl wang manya purum e

21. abulka menayl poyibi turum e

22. nui-nga nai tirim e

23. mepa ola oba a

24. ena-nga depa mulurum e

25. kapola kela purum e

26. na uj mong tulab e
Oh mother, oh me!

He jumped and rushed outside.

He jumped and ran to the house.

The flies began to buzz.

The mosquitoes began to drone.

"Now you just keep quiet," he said.

In my mind's eye the story unfolds.

A fine looking fellow was he.

His eyes made his nose look small.

His nose made his eyes look small.

In my mind's eye the story unfolds.

A very fine fellow indeed.

He jumped and rushed outside.

Then jumped and rushed to the house.

"In Mendi they're having a feast.

I'll go there tomorrow," he said.

"Rosa what woman are you?

My brightly coloured hat,

Please get it and wash it," he said.

Down she went to Puyl Creek.

She carefully washed it off.

It really did look fine.

She brought it back from the creek

And laid it out in the sun

And then she turned and left

"I'll cut some growths from tree trunks"

The use of formulaic expressions is exemplified by: the figure in lines $2-3$, which is repeated in lines 13-14 and ten more times later on in the performance; the figure in line 7, which is repeated in line 11 and thirty times later on; the figure in lines $9-10$, which is repeated once in this performance in a variant form and often used in other performances; and the figure in line 22, which is repeated once in this performance and also commonly used in others. Note that in each case the figure comprises one whole line or two of them in sequence. By way of explanation, the standard two-line figure in lines 9-10 in effect amplifies on what is said in line 8 , that the young man who is being referred to is very good looking - large eyes and noses being considered attractive features.

The use of parallelism - repetition with variation - is exemplified in lines 2-3, $4-5,9-10$, and 13-14. Note that in each case, the unit within which this variation is found is the line. That is, both the elements that are repeated and those that are varied occur at corresponding positions within adjacent lines. As discussed in Rumsey (2007:261-66, 269-70), this both contributes to the salience of the line as the basic building block of tom yaya kange in general (as in all the other sung story genres treated in this volume) and draws on the enhanced possibilities for parallelism that are afforded by the fixed line-length in metrical variants of tom yaya kange such as Konts's. As is true of parallelism in other regional 
genres discussed in this volume (in chapters 4 and 8) and in many other genres of verbal art around the world (Jakobson 1960, Fox 1977, Fabb 1997), the terms that are placed in a parallel relationship with each other typically are ones with meanings that are closely related to each other, either as antonyms or as other kinds of contrasting terms within a given semantic domain (so called "semantic parallelism"). This is true of all the parallel terms in text 1, that is, pena 'outside' / lku-d 'into the house'; olu-ma 'flies' / lupal-ma 'mosquitoes'; ngil 'buzz' / tom 'drone'; and mong 'eye' / kubi 'nose'. Note that the parallelism in lines 9-10 is of a more elaborate kind known to classical rhetoric and poetics as "chiasm" (lit., 'shaped like the letter X'), in which both of the contrasting terms occur in each of the two parallel lines, in reversed positions as between the two (eye ... nose / nose ... eye).

In addition to the occasional grouping of lines into parallel pairs (and sometimes larger sets; see Rumsey 2007:264-66 for examples), tom yaya kange are musically organized into repeating melodies consisting of an even number of lines of text, each of which can be considered to comprise, in musical terms, one measure. The general form of the melody used by Konts in the performance associated with text 1 is shown in cipher notation in figure 2 and in musical notion in figure $3 .^{8}$

$\begin{array}{lllll}1 & 1 & 1 & 5 & 5 \\ 5 & 5 & 6 & 5 & 2 \\ 5 & 5 & 3 & 4 & 4 \\ 2 & 2 & 3 & 2 & 2 \\ & & & & \\ 2 & 2 & 2 & 5 & 5 \\ 6 & 5 & 5 & 4 & 1 \\ 3 & 3 & 2 & 3 & 3 \\ 1 & 2 & 2 & 1 & 1\end{array}$

Figure 2. Basic form of 8-line tom yaya kange melody shown in cipher notation.

Figure 2 is useful for showing how Konts's melody maps on to individual lines and the words within them. In this particular performance, the melody begins in line 3. Line 1 stands outside of the melody, by having only four beats and no final vocable as discussed above, and also by having all of the words intoned on a single pitch, the same one on which the melody begins and ends. Line 2, although it has the same rhythmic structure as the following ones, differs from all of them

8 This melody, which is used by Konts in all of the performances of his that I have recorded, is very similar the one used by the renowned Melpa kang rom performer Paul Pepa as described by Niles in chapter 12, and indeed is modeled upon it. For details of the relationship between Pepa's work and Konts, see Rumsey (2006b). Note that the representation of this melody in figures 2 and 3 differs in some details from the one presented in Rumsey (2001:212) and Rumsey (2006b:326). This is a result of the instrumental-phonetic analysis that was done for Rumsey (2007) and of collaboration with Don Niles. The representation of the melody presented here and in Rumsey (2007) supersedes the earlier one. 
in being sounded at a single pitch - the same pitch as in line 1. Beginning with line 3 , each of the four words in each line and the final vocable are sung on the six respective pitches shown in each line in figure 2 and in each measure in figure 3. This same eight-line melody is repeated through Konts's performance, in lines $3-10,11-18,19-26,{ }^{9}$ and so forth.

Figure 3. Basic form of 8-line tom yaya kange melody shown in musical notation.

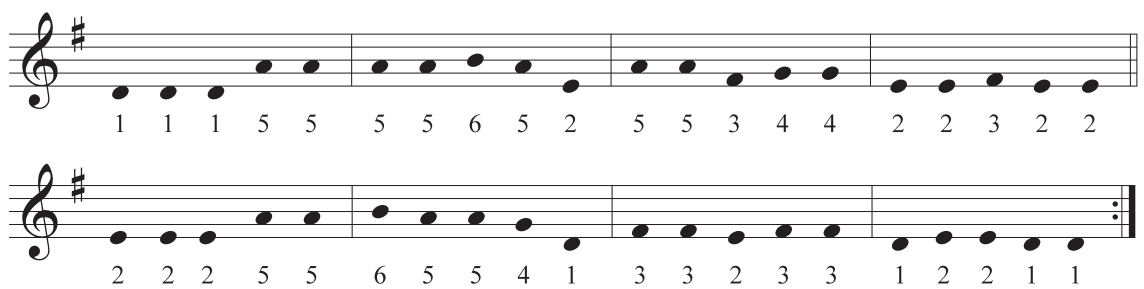

While the notes in these figures are not shown with any specific time values, as described above, each word or vocable with which they are associated is sounded over roughly same duration. So while figure 3 represents the general form of the melody, a musical transcription of, for example, line 19, would have a triplet on the first beat of the measure, pairs of quavers (eighth notes) on the second, third, and fourth, and crotchet (quarter note) on the fifth (along the lines of Niles's transcription of Paul Pepa's kang rom melody in chapter 12; for musical transcriptions from one of Konts's performances, see Rumsey 2007:246). The fact that the pitch movements within this melody generally map on to whole words or beats provides a further audible trace of the primary division of the line into five integral units.

Turning now to the overall shape of the melody, note that in figure 2 there is a close resemblance between: lines 1 and 5;2 and 6;3 and 7; and 4 and 8. This can also be seen in figure 3 , where the corresponding musical measures are shown directly above and below each other. From both of these figures it can be seen that the second half of the melody is a variation on the first half, with some of the notes in equivalent positions being identical and all the others being either one note higher or one note lower. As detailed by Niles in chapter 12, this elaborate form of musical parallelism has been found in all of the tom yaya and kang rom performances that have been analysed to date, in all song genres that have been analysed to date in the Melpa region, and in all but one genre in the $\mathrm{Ku}$ Waru region.

9 Note that although line 26 comes at the end of the melody, it does not come at the end of a textual unit. Rather, in terms of textual coherence, it goes with the following line (not shown in text 1), which is " You count them,' her brother told her." The frequent lack of fit between melody and textual units in sung tales is also discussed by Niles in chapter 12 (n. 15). 


\section{The translation of tom yaya style}

Given the range of linguistic and musical features discussed above, a major concern in my work on tom yaya kange has been to develop a way of translating them that will allow some of the effect of the original sung Ku Waru version to be carried over into written English, as per Dennis Tedlock's (1983:31-61) concept of the "translation of style." As in any attempt of this kind, there are at least two kinds of problems to be faced, one at the level of sound and the other at the level of sense.

At the level of sound, at least when translating the metrical varieties of tom yay a performance such as those of Konts, there is the problem that their metrical form is different than any of those used by poets working in English, insofar as it is based not on a distinction between strong and weak syllables, but on syllable timing and word boundaries as discussed above. ${ }^{10}$ Notwithstanding this difference, a basic fact about the tom yaya kange of Konts and almost all other bards within the $\mathrm{Ku}$ Waru region is that it does have a regular rhythm to it (as do all Melpa kang rom), with a fixed number of beats per line (albeit with different numbers of them in different styles). For that reason it seems to me most appropriate to translate their work into lines of English which also have a fixed number of beats per line.

What must differ as between English and Ku Waru is the way in which those beats are realized. Given the very different prosodic patterns of the two languages, any attempt to realise them solely by means of syllable timing and word placement within the line would fall flat on its face. Rather, I have found that what works best is to organize the lines into a fixed number of feet per line, each with one strong syllable, followed and/or preceded by up to two weak syllables.

But how many feet should there be in each line of the English translation? The same number as in the corresponding line of tom yaya kange? The answer to that question must depend in part on what we do about the vocable at the end of each line of tom yaya kange. As a vocable it is by nature not something that could have a literal "translation": it has no sense that we could attempt to capture with one. All that we could do would be to render it with another vocable, that is, to end with a corresponding sound at the end of each line of English, for example:

2. puku to pena purum e

3. puku to lkud urum e

4. olu-ma ngil nyirim e

5. lupal-ma tom turum e
He jumped and rushed outside e.

He jumped and ran to the house e.

The flies began to buzz e.

The mosquitoes began to drone e.

10 For further details concerning this difference and its implication for theories of poetic metre, see Rumsey (2010). 
But this is far too literal an approach to work in English. Paradoxically, it fails to capture the spirit of the original by reproducing it "to the letter" at the end of the line. So I have chosen to leave out the line-final vocables, allowing the fixed length and prosodic structure of the English line to serve as sufficient markers of the passage from one to the next.

Since the line-final vocable in the $\mathrm{Ku}$ Waru line fills one whole beat, if it is omitted from the English line, should that line include the same number of beats as the $\mathrm{Ku}$ Waru line minus one? Again, I have treated this as a matter to be settled by trial and error. The answer depends in part on the question "How long a line of English does one need in order to translate a line of tom yaya kange?" This in turn depends on the kind of English that one translates with. Different answers to that question are possible and viable in their own ways. An interesting approach which is quite different from mine is the one used by Dr. Joseph Ketan, a political scientist-cum-anthropologist who comes from the Hagen area, is a native speaker of Melpa, and has done extensive translation of kang rom sung tales from the region. Treating kang rom as a kind of "high art," Ketan attempts to capture that aspect of its style by translating it into relatively "high" sounding English, making frequent use of three- and four-syllable, often Latinate words, in preference to shorter Anglo-Saxon ones. This is exemplified by the following lines of his translation from the story of Kuma Pököt and Kopon Morok:

The Kumanian grasped the menacing club tightly

His rock-like knuckles curved in, forming an out of proportion ball;

Lifting the club with ease he let it fall;

The impact was devastating;

The skull of the pig was literally smashed to pieces. (Strathern and Stewart 1997:10) $)^{11}$

Would a similar "high style" of English be appropriate for translating tom yaya kange? In order to answer that question it is necessary to say more about the varieties of $\mathrm{Ku}$ Waru that are used in tom yaya kange performances. As discussed above, the performers make frequent use of parallelism and of formulaic expressions, many of which are themselves cast in parallel form. While neither of these features per se is unique to tom yaya kange, they are used there in ways that are highly distinctive of the genre. An example is the expression used in lines 7 and 11 of text 1: kanab a taka nyiba. As far as I know, this expression is never used except in tom yaya kange. What it literally says is 'As I see/watch,

11 These lines come from a translation that Ketan prepared from audio recordings and transcriptions of kang rom that he had produced with grants from the Institute of Papua New Guinea Studies in 1981 and 1982. The translation won an award in the lyrics section of the Papua New Guinea National Literature Competition (Joseph Ketan, pers. comm., 2006). During 2003-4 Ketan worked in association with the ANU based Chanted Tales Project, producing transcriptions and translations of kang rom performances by renowned Melpa bard 
quietly ...'. This is a standard formulaic line of the kind known to ethnopoetics as a "metanarrational" (Babcock 1977) formula, used by the performer to frame his narrative from the point of view of the performance event. My very free translation, "in my mind's eye the story unfolds," is based on the few exegeses I have been able to elicit concerning the precise import of this oft-repeated line (many other people giving answers like "It's there to make it sound good; to make it sound like tom yaya kange"). ${ }^{12}$

What is difficult about this line is not any of the words in it, all of which are perfectly ordinary ones in $\mathrm{Ku}$ Waru. Rather, what is difficult to understand is the sense of the line as a whole, as given in my literal translation above. There is a large-ish set of such metanarrational formulae that are used in tom yaya kange (as in kang rom), many of which are distinctive to the genre in the same way that this one is, that is, not in the words used in them, but in what the particular combinations of those words are used to mean within the context of tom yaya kange. (For further discussion, see Rumsey 2001:207-8.)

Some of the other expressions used in tom yaya kange include words that are not ordinary $\mathrm{Ku}$ Waru, but, rather, are said to be used only in tom yaya kange. An example occurs in text 1, line 21: menayl poyibi turum. The word turum is ordinary, being the third-person singular remote past form of the verb to- which when used by itself means 'to hit', but which also occurs regularly in combination with a preceding "verbal adjunct," in which context it means simply 'do'. ${ }^{13}$ But unlike turum, the preceding two words (menayl and poyibi) are said to occur only in tom yaya kange, where, in combination with turum and abulka 'holding', ${ }^{14}$ they can be glossed as 'she scrubbed till the dirt all came out' - the usual way of saying this would be no lelka kalaru-ma purum. Another example occurs in line 22: nuinga nai tirim. Again, the final verb - in this case tirim - is ordinary, being glossable in this context as 'did'. But the two preceding words nuinga nai-in the sense in which they are used here, 'to look exceedingly fine' - are said to occur only in tom yaya kange.

Totally genre-specific expressions such as this are relatively rare in tom yaya kange. In the great majority of lines, every word comes from everyday $\mathrm{Ku}$ Waru, from a more ordinary level of what literary scholars call "diction" than do expressions such as Ketan's "grasped the menacing club," "rock-like knuckles," or "out-of-proportion ball" in English. And as noted among the features of tom yaya kange listed above and discussed in detail in Rumsey (2007), the syntax of

\footnotetext{
12 I have felt gratified to find that, working totally independently of me on a translation of the tom yaya kange by Peter Kerua that is discussed by Don Niles in chapter 12, Melpa/Ku Waru speaker Gomb Minimbi has translated Kerua's very similar line kanaba taka nyiba e mudupa as 'let me silently see what's happening'. 13 For details of this and other related aspects of Ku Waru grammar, see Merlan and Rumsey 1991 (appendix B).

14 This is a form of the verb abul- 'to grasp in one's hand(s)' in which the root is followed by the third person singular "switch reference" marker $-k a$, indicating that its subject (the woman Rosa) is different from the subject of the next verb (Koka's hat). For details of this and other related aspects of Ku Waru grammar, see Merlan and Rumsey 1991 (appendix B).
} 
tom yaya kange is much simpler than in spoken $\mathrm{Ku}$ Waru, thereby increasing the salience of the isometric poetic line and the scope for poetic parallelism across lines. Accordingly in my translations I have chosen to use "everyday" English whenever possible, with short words and simple syntax.

Having made this choice and experimented with English lines of different lengths, I have settled on a three-beat line as the optimal length for translating tom yaya kange lines with five or six beats (including the line-final vocable). Note that this finding is conditioned in part by my having chosen to use a "plain" English style with shorter words over a "high" style with longer ones. This can be seen by contrasting the length of my three-beat lines in text 1 with that of the lines from Ketan's translation above

Besides the fact of its being metrical, another way in which the form of my English line matches that of tom yaya kange is in its great flexibility regarding the number of syllables that can be included within a foot-anywhere from one to three, with, in the case of my English line, one strong syllable in each foot that is preceded and/or followed by two, one, or no weak beats. So in total my quasitom-yaya line can consist of anywhere between three and eleven syllables, in the following pattern (where "S" = "strong syllable" and "W" = "weak syllable"):

$$
\text { (W) (W) S (W) (W) S (W) (W) S (W) (W) }
$$

Similarly, if we exclude the final vocable, the tom yaya kange line in its five-beat variant in principle can consist of anywhere between four and twelve syllables, and the six-beat line of between five and fifteen. If we ignore the vocables that are occasionally used within the tom yaya kange line to fill out the requisite number of feet (e.g., the $a$ after kanab in line 7 of text 1 ) the average number of syllables used within my three-beat line, for example in text 1 (7.16) is quite comparable to the average number used within both Konts's five-beat line (7.36). Similarly with respect to the six-beat line used by another performer, Noma, a count of syllables in the first twenty-five lines of his text on pp. 205-6 of Rumsey (2001) shows an average of 9.52 syllables per line, and 8.32 in my English translation.

In sum, by not imposing any particular structure on my English foot, I have not only allowed it (in terms of syllable count) to match closely that of the $\mathrm{Ku}$ Waru original, but have also allowed for a similar degree of variability in the number of syllables that may occupy it, while nonetheless maintaining a line which is of quite constant overall duration. This is possible both in $\mathrm{Ku}$ Waru and in English because they happen to be similar in one key respect, namely in the great variability of syllable length which is permitted in each. ${ }^{15}$

15 In this respect both $\mathrm{Ku}$ Waru and English differ from what are known as "syllable timed languages," in which syllables are purportedly of more even duration (Pike 1972). French is often cited as a language of this kind. It is unclear whether it actually is, or whether languages of this type actually exist (Pamies Bertrán 1999), but if they do, $\mathrm{Ku}$ Waru is not one of them, at least in the way it is used in tom yaya kange. For instrumental- 
Turning now from the realm of sound to that of sense, note that this topic has already been broached by my discussion of diction above and my sense of the greater appropriateness of a "plain" style than of a "high" one for translating tom yaya kange. Both at that gross level of distinction and at that of particular choices to be made on a word-by-word and expression-by-expression basis, there are important questions of cross-cultural disparity and/or analogy to be faced. These concern not only individual words, but the range of senses or connotations that can be expressed by them.

For example, a frequently-used word in many tom yaya kange performances is kang, which in its literal sense means 'boy'. This same word can in certain contexts be used in reference to young men and, indeed, to men of almost any age as an alternative to the word $y i$ 'man'. When used in the latter way it entails a connotation of high-spirited male camaraderie. Casting about for a word to translate it, I have settled on the word 'lad' as one which is appropriate on two counts. First, it is appropriately colloquial (by contrast with, for example 'youth' or 'juvenile'). Second, like kang, 'lad' is used primarily in reference to boys, but also to men, also with connotations of high-spirited male camaraderie.

A case of a $\mathrm{Ku}$ Waru word that is used in an even more extended sense is kis, the ordinary sense of which is 'bad' or 'ugly'. Especially in tom yaya kange it is often used in exactly the opposite sense 'very good' - not in the moral sense, but in the sense of 'fine', 'marvellous', or 'good looking'. This range of senses is quite comparable to uses of the word 'bad' or 'bad-ass' in US Black Vernacular English. So I have translated it in both of those ways.

In some cases the problem of how to translate particular words and expressions is tied up with the issue of how to convey the force of a larger metaphor in which they figure (metaphor being a frequent and highly valued feature of tom yaya kange). An example occurs in the last two lines of the following passage from the story of Kubu Suwakl, as performed by Peter Kerua (online item 18 is a short excerpt on video of another performance by Kerua of the same tale from which these lines are taken; an image from this recording has been used on the cover of this volume):

abu waipi mele kaniyl-e ukulu-kilye manya mele purum-e abolurum abolurum kana poin sukusingi kanarumu nal sukusingi kanarumu kanab taka nyiba mudupa lapisa abolupa aji mudurum-o bras paku mela tirim-e kanab taka nyiba mudupa kurali gel mel kanital-e napilya mulyi no okupa pijirim-e
That woman whose name was Wapi Went down to the banks of the Ukuglu. And washed herself over and over Till she shone like the wood of a poin tree Till she shone like the wood of a nakl tree. In my mind's eye the story rolls on.

She carefully groomed her hair And put on a black-bead necklace In my mind's eye the story rolls on. The flowers adorning her loin cover Were sluice gates in the River Nebilyer. 
The metaphor in the last two lines likens the front middle part of Wapi's flowered loin cover - the part over her vagina - to the middle part of a weir that has been built across the Nebilyer River to channel its flow in order to catch fish. The Nebilyer is the biggest, most powerful river in the region. In the interpretation offered by my translation assistants (John Onga, Thomas Pai, and the composer/ performer Peter Kerua), this metaphor in effect likens Wapi's erotic energy to the powerful, turbulent flow of the Nebilyer, which has been channelled and concentrated by a sluice gate just as hers has been channeled and concentrated on the male hero of this story, Kubu Suwakl. Other possible translations of the last line would be 'were like a fish trap in the Nebilyer River' or 'made the water overflow in the middle of the Nebilyer'. My translation 'were sluice gates in the River Nebilyer' is based on my understanding of the overall force of the metaphor, for which the relevant fact about the apparatus that it is being compared to is not that it used to catch fish or to make water overflow, but that it has the effect of channelling and intensifying the flow, as does a sluice gate. I have chosen the wording 'were sluice gates in the River Nebilyer' also because it meets my requirement that each line have three strong beats ('were slúice gates in the Ríver Nébilyer), because of the abundance of sibilants in the phrase 'sluice gates' and the sibilant-liquid cluster at the beginning of it, all of which aurally reinforce the idea of flow and sexual energy that the image is about.

\section{The plots of tom yaya kange and kang rom}

In previous publications I have emphasized the similarities among the plots of tom yaya kange relative to the wider range of them that is found among kange tales more generally (i.e., including those that are spoken as well the ones that are sung). I have said that many of them

[cluster] around a prototypical plot in which a young man sets out from his home to court a young woman he has heard about in a far-away place, undertakes a long and arduous journey to her home, wins her hand, but then encounters various obstacles in his attempt to bring her back to his home and marry her, sometimes succeeding and sometimes not. (Rumsey 2006b:322; cf. Rumsey 2001:201)

But in light of more recent experience, especially at the 2006 Goroka Chanted Tales Workshop, I have become more mindful of the differences in this respect between the Melpa and $\mathrm{Ku}$ Waru regions, and, within the $\mathrm{Ku}$ Waru region, between the eastern and western reaches of it. Plots that conform to the above description are most prevalent among sung stories by performers within the Melpa region (kang rom), especially within the past generation or two. At the 2006 workshop we were told by a knowledgeable senior Melpa man, Ru Kundil, ${ }^{16}$ that there are

16 For a biography of Ru, see Strathern (1993) and Strathern and Stewart (2000). 
currently only two kang rom stories that are ever performed: the story of Kwint Wöp and Morokla Rakop, and the story of Miti Krai and Ambra Rangmba. Both are prototypical tales of courtship. ${ }^{17}$ The predominance of these two tales in recent times is no doubt due in part to the huge impact of performances of them by Melpa bard Paul Pepa which were recorded and broadcast on Radio Western Highlands during the 1980s, and widely disseminated through cassette copies that were made of the broadcasts by interested listeners, as discussed by Niles in chapter $12 .{ }^{18}$ Other recordings of the Miti Krai-Ambra Rangmba kang rom tale by other performers were recorded by archaeologist Ole Christensen in 1974, by Radio Western Highlands in 1981, ${ }^{19}$ and by Andrew Strathern in 1982 (Strathern and Stewart 2005b:224).

Besides the two tales named by Ru (Kwint Wöp-Morokla Rakop and Miti KraiAmbra Rangmba), there is evidence for a somewhat wider range of tales having been performed in the Melpa region both in the fifteen years before Pepa's first broadcast (1965-80) and during the following eighteen years (1981-98). Recordings were made during that time by Andrew Strathern of at least two other tales by other performers. Both are tales of courtship. One is about a man named Kuma Pököt, who courts a woman named Kopon Morok (or, in some variants, Rangmba). This tale starts out with the usual sequence in which the male protagonist sees a smoke signal from the young woman's distant home, travels there after elaborate preparations, wins her hand and her father's blessing, and brings her back to his home. But Morok finds that the rival suitors from her village have followed them to Pököt's. They take her back, but she leaves a lock of her hair for Pököt, moistened with her tears and wrapped in a leaf. When Pököt finds it, he goes insane with grief and hangs himself. ${ }^{20}$

The other tale recorded by Strathern (in 1965) is that of Mukl Miti Weipa and Kundila Rangmba (Rangkopa). That tale is a variant of the above, which unfolds in the same way up to the point when Weipa leaves with his new bride to return to his home village. Then as they are travelling home they notice smoke rising from Rangmba's village. Weipa goes back to check up and finds that Rangmba's other jealous suitors have set fire to her parents' house and killed them. Weipa attacks them in retaliation, but they succeed in killing him. He then sends his spirit to Rangmba to guide her back to his village. Not realizing that her guide is

17 For a plot summary and discussion of the latter, see Strathern and Stewart (1997:6-7) and Stewart and Strathern (2002:124-25).

18 For further details concerning Pepa and those performances, see Rumsey (2006b) and Niles (2007).

19 Transcriptions and translations of the Christensen recording (by a performer named Michael) and the Radio Western Highlands one (by a performer name Karaip of Gumants) have been made by Gomb Minimbi and are held by the Institute of Papua New Guinea Studies in Port Moresby.

20 For a fuller summary of the plot of this tale and discussion of it, see Strathern and Stewart (1997:4-5; 2002:50-51) and Stewart and Strathern (2002:123-24). 
a ghost, when she arrives there she sees Weipa's body being carried in for burial. Mortified, she chops off several of her fingers with an axe. She mourns Weipa's death for three days, then stays with his kinsfolk for the rest of her life. ${ }^{21}$

In short, there are eight or nine Melpa kang rom performances, by six or seven different performers, ${ }^{22}$ that have been recorded since 1965 for which we have transcripts or other information about their plots. Among them there are four different tales as identified by main characters and plot. All of them are tales of courtship with variants of the "prototypical plot" as summarized in the quote from Rumsey (2001) above.

By contrast, in the $\mathrm{Ku}$ Waru region, of the performances of twenty-five tom yaya kange that I recorded and transcribed between 1982 and 2006, ten are tales of courtship which conform to the prototype. The plots of three more include courtship as one of the elements, and twelve do not include events of courtship at all. In other publications I have included a plot summary of one of the tom yaya tales involving courtship (Rumsey 2005:60-61), a full free translation of another (Rumsey 2005:54-59), and a full line-by-line transcription+translation and free translation of another tale that does not include courtship at all (Rumsey 2001:228-39; 2006b:341-42). For present purposes, in order to the exemplify the wide range of plots found in tom yaya kange, in what follows I present briefer synopses of the latter two tales (texts 2 and 6), and of three others: ${ }^{23}$

Text 2. "Kupi Tagla and Kalkala Tanga," by Engal Kep. Recorded 15 February 1997.

There was a woman at Kalkagla called Tanga and a man up at Kupi called Tagla. Tagla went up to Mount Kaylkenga and saw a fire burning in the distance. He came home, told his mother and father about it, and said he wanted to go and see the place. They told him not to, but finally gave in. They helped him roast a pig to provide him with pork for the journey. He adorned himself and set off to court the lass at Kulkagla that he had heard of named Tanga. He walked and walked, until he came to Kulkagla where he found Tanga living with her sisters. They all wanted to marry him but she and Tagla only had eyes for each other. The women loaded up Tanga's netbag with roast pork and said, "You two can go, but when you get home this woman will not go into your house. Let her

21 For a fuller summary of the plot of this tale and discussion of it, see Strathern and Stewart (1997:5-6) and Stewart and Strathern (2002:124 (cf. 113-18)).

22 The reason for the uncertainty as between eight or nine performances and six or seven performers is that it is unclear whether the two performances recorded by Christensen - both of the Miti Krai-Ambra Rangmba tale or portions of it - were by the same performer or different ones.

23 For plot summaries and discussion of two other tom yaya kange that differ from all the ones presented here in being set in contemporary Papua New Guinea, see Rumsey (2005:60-66); compare also the discussion of them in chapter 1 of this volume. 
sleep in the middle of the road." When Tanga and Tagla got back to Kupi, she refused to go into the settlement and stayed out in a nearby meadow. Tagla rejoined his parents, who thought he had come back emptyhanded. Next morning when Tagla returned to the meadow, he found that Tanga had magically transformed it into a beautiful hamlet with a long display ground, abundant gardens, countless tubes of precious tree oil, and rows of tethered cassowaries and fattened pigs. They settled down to a prosperous life together. With Tanga's support, Tagla became a leading big-man. Then he started thinking about what he had been told by Tanga from the start: "We will not do as husband and wife. You and I can't even think of that." He became angry and stopped eating. Tanga asked him, "What are you thinking about? Are you thinking of doing as man and wife?" This made Tagla feel better. They slept together in the bedroom. In the middle of the night the woman left. When the man awoke, he found himself out in a bog, covered with mud from head to foot. "My wife!" he said. "My cassowaries! My fat pigs! My tree oil! Where have all my things gone? Where has my wife gone?" He grew hungry, but had nothing to eat. He became shabby and dishevelled. His face became covered with snot. He wandered in and out of the forest, until one day he died in the middle of the bush.

Text 3. "Forest Man Nikindi (Uj Punya Nikidi) and Randam," by Konga. Recorded 15 February 1997.

There once was a beautiful lass named Randam. She was courted by men from all over, but she only wanted to marry Nikindi, the man from the forest. His parents agreed to it and the two of them set out to Nikindi's place together. As they went up Mount Bombo and looked back, they could see that Randam's parents' house was on fire. Nikindi told her to wait there while he ran back to check what had happened. When he got there the other jealous suitors threw him into the fire. His ghost came back to Randam and continued on the homeward journey with her. They stopped for the night in a broken down house on the way. When Randam tried to turn Nikindi towards her, he looked like a mouldering log. She realized he was a ghost. Next morning she went on to his home where she was greeted by his parents. She told them of his death. They invited her to live with them. She gave birth to a baby boy. One day as they were stopping in a bamboo grove, a big wind blew it over and killed both of them. 
Text 4. "Kalya Dom and Rangamb," by Michael Moda. Recorded 15 February 1997.

A man named Kalya Dom courted a woman named Rangamb. She wanted to marry him, but then he disappeared. He took off his good skin and wore his ugly one instead. He had done this with several of his wives before. One day there was a celebration. Dom put on his good skin for it. He joined the line of dancers with his drum. When the dance was over, he put down his drum while he was taking off his feathers and face paint. An old man stole the drum and ran off with it. Dom chased him but couldn't catch him. Then the old man, who turned out to be a cannibal, grabbed him and threw him down into a ravine where he was holding others captive. After several weeks down there, Dom found some feathers, put them on his sides, and flew away. Then he came back and showed the others how to do the same thing. They then went to the place from where the cannibal had thrown them into the ravine and waited for him in hiding. They saw him return, take a rope out of his bag, tie it to a tree, and start to climb down into the ravine on it. They cut the rope and he fell down the ravine and died. Then Dom told everyone to fly back to their own places, which they did, himself included. When he got there he saw that his mother was crying and had cut her fingers off. "Don't cry Mother," he said. "I'm coming." She and his father were living in a cave where Dom had hidden them. Saying a magic spell, he joined his mother's fingers back to her hand. Next morning he went to the wives he had abandoned and found that they had cut off their fingers too. He magically healed them too and then disappeared again. Rangamb secretly followed him. On the way he transformed himself into a bird, then a snake, and then a pig, but Rangamb still kept up with him. He became a bird again and flew into the cave where he had put his parents. Still following him, Rangamb then revealed herself and said, "Why have you left all us wives and come here?" She then went back and rounded up all the wives, brought them to the cave, and led an attack on Dom and his parents. The parents disappeared and the cave then closed up around the wives, crushing them and killing them. Several days later it opened up again. Their parents came and took their bones back home and held funerals for them. The parents lived and died in due course.

Text 5. "Telima Tiyl and His Dog Peant," by Philip Win. Recorded 16 February 1997.

A boy named Telima Tiyl from Winjaka went out with some other boys to the sweet-potato gardens to hunt rats. After clubbing quite a few of them, they said, "Let's make a fire to cook them." They pretended they couldn't get their fire starters to work. Tiyl said, "Look, there's a fire burning 
down there at Pikiyl Plain; I'll go get some embers to light our fire with." As he was doing so, they made a fire, cooked and ate all the rats, and left. When Tiyl came back with the embers and saw what they had done, he cried and cried. Deciding to run away, he gathered some cuttings of cane grass, sugarcane, and greens, and set out for Mount Giluwe with his pet dog Peant. When they got there they slept out in the cold. Next day they cleared some land with their machetes and planted the shoots they'd brought. Peant hunted down some possum for them, which they lived on till the gardens grew. Down at Kondumanda, Peant found a tethered sow, untied her, and let her back to their camp. She bore sixteen piglets for them. Then Peant set off to find a wife for Tiyl to tend the gardens and pigs for them. He came across some young women bathing in the river. He lay down on the netbag that one of them had left by the river bank. She could see that he was a special dog. She let him spend the night in her house, then lead her back to Telima Tiyl. They killed a pig and feasted her. She and Tiyl were smitten with each other. He gave bridewealth to her family and they were married. She bore Tiyl two sons. At first she and the dog Peant got on well, but then she got tired of having him around. One day when she came into the house, overburdened with a big bag of sweet potatoes on her back, and saw him lounging by the fireside, she got angry and kicked him away. Peant was devastated and decided to run away. When Tiyl returned, he heard Peant howling in the distance and realized what had happened. He was mortified and cut off his fingers. Peant went back to Mount Giluwe and never returned. The pigs that Tiyl and Peant had raised remained, but only in empty half-sections; the other half of each of them was up at Mount Giluwe with Peant.

Text 6. “A Small Boy,” by Kopia Noma. Recorded 2 February 1997.

A small boy goes out and single-handedly vanquishes the enemy tribes. He returns home to his adoptive mother, who is unimpressed. She tells him to stay home and work on planting gardens, tending pigs, and building a house so he can find a wife. They quarrel. She tells him a story of a child like himself who killed people, including a pregnant woman. She told him how the boy in the story cut the baby boy from the pregnant woman's belly, took it home, and gave it to his mother. She looked after the baby until it became a young man - a disobedient one. He wandered and did not look after the pigs he would need to pay brideprice. One day he overheard a conversation in which the father figure complained about the boy and told the adoptive mother about how he had gotten him from the slain woman's belly. When the young man heard this he cried and cried. Then he took the father's axe and ran away. He came to a clearing where there was a man who welcomed him and invited him to spend the 
night. There was a woman there roasting food and, when she saw the young man, she threw her arms around him and cried, saying "Where have you been?" When the couple heard the boy's story, they invited him to live with them, and offered to build a house for him. He gave them the axe he had brought with him. There were many men there and they passed the axe around amongst them and inspected it. The young man took the couple as his true father and mother. They took him to the river bank and showed him the trees he could cut down the next day to make his house. But when he got there the next morning, he saw that the trees had already been felled and the posts all prepared for building the house. With the others' help, he took the posts to where they were going to build the house. Next morning he came and saw that they had already erected the frame. Then next morning he came and saw that they had finished building the house and pig stall, and that it was full of pigs. He looked at them closely and found that they were the same pigs that he had been raising back at the other place. The couple said to him, "You think you are somebody else, but you are our own true son. Now you have come back to us. Here are your fattened pigs, and there is a whole bag of kina shells for you. Now you can find a wife or do whatever you like. We are overjoyed that you've come back." They got him a wife and did everything they said they would.

With respect to role played in their plots by courtship, these texts provide a roughly representative sample of tom yaya kange that I have recorded, as can be seen by comparing them with the overall ratio I have reported above of ten stories in which courtship is central, three in which it plays a part but is not central, and twelve stories in which courtship plays no part. Likewise, courtship plays a central role in two of the above texts, but not in the other three (although the importance of finding a spouse does figure as a theme in them). Only one of the texts, text 2, includes the opening sequence which is present in most or all of the eight or nine recorded Melpa kang rom, in which the young man learns of the desired young lady through the sight of distant smoke from a fire that she has lit, decides to go court her, adorns himself for the journey, and kills and roasts a pig to take with him.

But while the story in text 2 is similar to the kang rom in that respect, as pointed out by Strathern and Stewart (2005a:16), it differs from any kang rom they have ever come across in casting the courted woman as one with magical powers who endows the man with great wealth and prosperity on condition that he not betray his oath to her. They observe that, while not found in kang rom, this is a theme that is well attested "in many of the other mythological genre materials that we have analysed, as well as in other materials from the Melpa area" (ibid.). ${ }^{24}$ They

24 See also chapter 10 for a similar story told among the Angal (Mendi) people. 
identify the courted woman Tanga in text 2 as a version of the Female Spirit, who, as discussed in chapter 1, figures in myths and in rituals that were formerly practised across much of the sung-tales region.

Likewise, the plots of all the other tom yaya kange summarized above draw upon motifs which are common in myths of the region (cf. Lepi and Bowers 1983, Vicedom and Tischner 1977, LeRoy 1985), including the themes of the "second skin" and the cannibal ogre in text 4 , the exile and return of the long lost son in text 6 , and the human-like pet dog as guardian in text 5, which indeed has a family resemblance to the Female Spirit, as does the overall plot of text 5 to that of text $2 .{ }^{25}$ These are just a few of the wide range of motifs and plots found in the full set of twenty-five tom yaya kange. The point here is that even the sample of five texts above displays a much wider range of plots than do the eight recorded kang rom.

But there is evidence that the exclusive association in the Melpa region between kang rom performance style and plots of courtship is a fairly recent development, dating back no more than fifty years or so. This was suggested by $\mathrm{Ru}$ at the 2006 workshop. After saying there are only two kang rom that are performed any more, he went on to contrast this with an earlier period when quite a few more than that had been performed. He cited four examples, only one of which, as far as I know, may include courtship as one of its main elements: the story of Ndepana Nikints. ${ }^{26}$

There is further evidence from another quarter for the now-standard kang rom plot of courtship not having been so central in the Melpa region within the relatively recent past. This comes from a collection of Myths and Legends from Mount Hagen which was recorded by the Lutheran missionary Georg Vicedom beginning in 1934 (just one year after the first arrival of Europeans in the area). The collection-originally published in German as Vicedom and Tischner (1943, vol. 3) and translated in a somewhat abbreviated version by Andrew Strathern (as Vicedom and Tischner 1977) — contains ninety-two texts. Vicedom says that while it is not exhaustive, the collection "does include all the myths which are general knowledge in the society." Given this claim, and Stewart and Strathern's (2002:135) observation that Hagen kang rom "are based on stories that are also told as spoken folk tales," it is striking that none of the ninety-two texts shows anything like the canonical kang rom plot of courtship-

25 For mention of a Duna (Yuna) pikono tale on the theme of dog as guardian with magical powers, see the discussion of pikono plots by Kendoli in chapter 2. For an example from the Melpa region, see Stewart and Strathern (2002:104-6).

26 I say may include courtship because the Melpa name Ndepana Nikints is cognate to the name of the leading character Uj Punya Nikidi in text 3 above, which is centrally concerned with courtship. But the Melpa story of Ndepana Nikints that Andrew Strathern recorded in 1964, as presented and discussed in Stewart and Strathern (2002:109-13), does not include an element courtship at all, and is instead a story about the relationship between Ndepana Nikints and his sister. 
even in the section entitled "Love Stories." The one that comes closest to it is tale no. 85, "Waipa from Pundupukl," ${ }^{27}$ which has a family resemblance to the tale of "Miti Weipa and Kundila Rangopa" as summarized above and presented in Stewart and Strathern (2002:123-24). In both tales there is a main male character named Weipa (Waipa) who successfully courts a young woman named Rangapa (Rangkopa). But in the kang rom version that Andrew Strathern recorded in 1965, the courtship scenario - including a fatally interrupted journey by Rangapa and Weipa back to his home-comprises the entire plot. By contrast, in the version that Vicedom recorded in the 1930s (Vicedom and Tischner 1977:120-23), the courtship scenario comprises just the opening episode of the story, which is followed by another thematically unrelated one in which Rangkopa is killed, then another in which Waipa tries unsuccessfully to avenge her death, and finally by another in which he successfully does so with the help of another man.

We do not know whether the tale of Waipa from Pundupukl was ever performed in a sung kang rom version during the period in the 1930s when Vicedom recorded it. No mention of kang rom is made by him or, as far as I know, by any other ethnographer of the region prior to Andrew Strathern's first recording of one in 1965. What does seem clear is that the plot of the kang rom version of the Weipa tale he recorded at that time, by Oke Korpa at Kelua (near Ogelbeng, where Vicedom had worked) was adopted by drawing selectively on a pre-existing tale in such a way as to highlight the element of courtship, thereby contributing to the development of an association between kang rom performance style and plots which were structured entirely around that element.

\section{Why courtship?}

Commenting on the appearance of the Female Spirit theme within the tom yaya performance summarized in text 2 above (and translated in its entirety in Rumsey 2005:54-59), Strathern and Stewart (2005a:16) remark that by combining this theme with the "classic balladic themes" - that is, the general model of courtship that they have the called the "romance of exogamy" - the performer has "brought two separate aspects of 'cultural tradition' together." In light of the evidence discussed above we can see that the model of courtship as the central one for kang rom narratives may well be a fairly recent "cultural tradition."

Whether or not that is the case, how are we to account for the current exclusive association in the Melpa region between kang rom performance style and plots of courtship, and the significant tendency in that direction as regards tom yaya performance style in the $\mathrm{Ku}$ Waru region? As discussed above, one factor that

27 As discussed by Niles in chapter 12, this same tale is included in Vicedom (1937). 
has certainly played a part since 1980 has been the performances by Paul Pepa that were broadcast over Radio Western Highlands, both having been tales of courtship. ${ }^{28}$

Another possible factor-not unrelated to the above-concerns the nature of the relationship between the performer and the protagonists in the story. As for the performer, there is, as I have discussed elsewhere (Rumsey 2001:218), "a strong sense of personal charisma associated with command of the tom yaya genre." Good performers are admired for the power they exert over their audience by overwhelming them with "a ceaseless flow of sound that keeps their attention focused on the story and makes them see and hear it in their own minds as the performer does in his or hers" (ibid; cf. Kendoli, this volume, regarding Duna performers). In other publications (Rumsey 2005, 2006b), I have shown how tom yaya performers tend to present the tales as if they themselves are stepping into the narrated world and taking the part of the protagonists or interacting with them. This is a two-way process, in that by doing so the performers also bring aspects of the narrated world into the here-and-now, identifying themselves with the protagonists, implicitly, or even explicitly in the case of Paulus Konts, who regularly casts himself as the central male character (Rumsey 2005:60-66; 2006a:58, 62).

In the case of the narratives of courtship, there is an especially close fit between the ideal persona of the tom yaya performer as a charismatic agent within the world of the performance event and the ideal persona of the central characters in the narratives of courtship, who are, as Stewart and Strathern (2002:132) have aptly put it, "magical character[s], supremely full of vitality and a sense of [themselves]." I suggest that one of the reasons for the association of tom yaya / kang rom performance style with the plots of courtship, at least in the modern context, ${ }^{29}$ is the close affinity between these two personae. Within the performance event, the figure of the bard in relation to his audience is metaphorically aligned

28 This influence was apparently greater in the central Melpa, Meam, and eastern Ku Waru regions than it was in the northern Melpa region. Andrew Strathern (pers. comm., July 2010) reports that "in Northern Melpa most people at this time did not listen to the radio and were probably not aware of Paul Pepa." By contrast I can report that Radio Western Highlands was widely listened to at Kailge, in the eastern Ku Waru region (western Nebilyer Valley) by the time Francesca Merlan and I did our first fieldwork there in 1981, that copies of Paul Pepa's performances were made on the radio-cassette recorders that had become popular by then, and that these were often played back to highly attentive audiences. The fact that Pepa's performances were in Melpa, rather than $\mathrm{Ku}$ Waru, presented little or no obstacle to their intelligibility, as most Ku Waru and Meam speakers in that region can also understand Melpa.

29 I include this qualification in view of a comment that Andrew Strathern (pers. comm., July 2010) has made to me that "the identification you suggest between the performer and the protagonist is intriguing but may belong more to recent commodified and dramatized contexts than to older ones. Oke [Korpa, whom Strathern recorded in 1965] never gave any semblance of an indication of such an identification, though in general both the protagonist and the performer (the former created by the latter) are certainly to be seen as special characters, in quite different ways." 
with that of the suitor in relation to his beloved. The extraordinary powers of each of these two figures are amplified by their identification with those of the other.

\section{Acknowledgments}

I wish to thank: Francesca Merlan, Don Niles, Pamela Stewart, and Andrew Strathern for their helpful comments on earlier versions of this chapter; Don Niles also for the inspiring interdisciplinary collaboration that has made the Chanted Tales Project and this volume possible; Paulus Konts and Peter Kerua for their wonderful tom yaya performances, and for permission to record and reproduce the ones discussed in this chapter; other $\mathrm{Ku}$ Waru friends who have assisted with the recording and study of tom yaya kange over the years, especially John Onga, Andrew Noma, and Thomas Noma; the Australian Research Council for funding the Chanted Tales Project during 2003-6; Australian National University (Research School of Pacific Studies, now the ANU College of Asia and the Pacific) for providing an ideal home for the project, and support for my research in Papua New Guinea since 1996.

\section{References}

Babcock, Barbara. 1977. "The Story in the Story: Metanarration in Folk Narrative." In Verbal Art as Performance, edited by Richard Baumann, 6179. Prospect Heights, IL: Waveland Press.

Fabb, Nigel. 1997. Linguistics and Literature: Language in the Verbal Arts of the World. Cambridge, MA: Blackwell.

Fox, James J. 1977. "Roman Jakobson and the Comparative Study of Parallelism." In Roman Jakobson: Echoes of His Scholarship, edited by Cornelis H. van Schooneveld and Daniel Armstrong, 59-90. Lisse: Peter de Ridder Press.

Jakobson, Roman. 1960. "Closing Statement: Linguistics and Poetics." In Style in Language, edited by Thomas A. Sebeok, 350-77. Cambridge, MA: Massachusetts Institute of Technology Press.

Lepi, Pundia, and Nancy Bowers. 1983. "Kaugel Stories: Temane and Kangi." Oral History 11 (4): 1-145.

LeRoy, John. 1985. Kewa Tales. Vancouver: University of British Columbia Press. 
Merlan, Francesca. 1995. "Narrative Genres in the Western Highlands of Papua New Guinea." In SALSA II: Proceedings of the Second Annual Symposium about Language and Society, Austin, edited by Pamela Silberman and Jonathan Loftin, 87-98. Texas Linguistic Forum, 34. Austin: University of Texas.

Merlan, Francesca, and Alan Rumsey. 1991. Ku Waru: Language and Segmentary Politics in the Western Nebilyer Valley, Papua New Guinea. Studies in the Social and Cultural Foundations of Language, 10. Cambridge: Cambridge University Press.

Niles, Don. 2007. "Sonic Structure in Tom Yaya Kange: Ku Waru Sung narratives from Papua New Guinea." In Oceanic Music Encounters-the Print Resource and the Human Resource: Essays in Honour of Mervyn McLean, edited by Richard Moyle, 109-22. Research in Anthropology and Linguistics Monograph, 7. Auckland: University of Auckland.

Pamies Bertrán, Antonio. 1999. "Prosodic Typology: On the Dichotomy between Stress-timed and Syllable-timed Languages.” Language Design 2: 103-30.

Pike, Kenneth L. 1972. "The Intonation of American English." In Intonation, edited by Dwight Bolinger, 53-83. Harmondsworth: Penguin. (Orig. pub. 1945.)

Rumsey, Alan. 2001. "Tom Yaya Kange: A Metrical Narrative Genre from the New Guinea Highlands." Journal of Linguistic Anthropology 11 (2): 193239.

2005. "Chanted Tales in the New Guinea Highlands of Today: A Comparative Study." In Expressive Genres and Historical Change: Indonesia, Papua New Guinea, and Taiwan, edited by Pamela J. Stewart and Andrew Strathern, 41-81. Anthropology and Cultural History in Asia and the IndoPacific. Hants: Ashgate Publishing.

2006a. "The Articulation of Indigenous and Exogenous Orders in Highland New Guinea and Beyond." The Australian Journal of Anthropology 17 (1): 47-69.

2006b. "Verbal Art, Politics and Personal Style in the New Guinea Highlands and Beyond." In Language, Culture, and the Individual: A Tribute to Paul Friedrich, edited by Catherine O’Neil, Mary Scoggin, and Kevin Tuite, 319-46. Munich: Lincom.

- 2007. "Musical, Poetic, and Linguistic Form in Tom Yaya Sung Narratives from Papua New Guinea.” Anthropological Linguistics 49: 237-82. 
- 2010. "A Metrical System that Defies Description by Ordinary Means." In A Journey through Austronesian and Papuan Linguistic and Cultural Space: Papers in Honour of Andrew K. Pawley, edited by John Bowden and Nikolaus Himmelmann, 39-56. Pacific Linguistics, 615. Canberra: Pacific Linguistics.

Stewart, Pamela J., and Andrew Strathern. 2002. Gender, Song and Sensibility: Folksongs and Folktales in the Highlands of New Guinea. Westport, CT: Praeger.

. 2005. "The Death of Moka in Post-colonial Mount Hagen, Highlands, Papua New Guinea." In The Making of Global and Local Modernities in Melanesia: Humiliation, Transformation and the Nature of Cultural Change, edited by Joel Robbins and Holly Wardlow, 125-34. Anthropology and Cultural History in Asia and the Indo-Pacific Series. London: Ashgate Publishing.

Strathern, Andrew. 1971. The Rope of Moka: Big-men and Ceremonial Exchange in Mount Hagen, New Guinea. Cambridge Studies in Social Anthropology, 4. Cambridge: Cambridge University Press. (re-issued with corrections and new preface, 2007.)

. 1974. Melpa Amb Kenan: Courting Songs of the Melpa People. Boroko: Institute of Papua New Guinea Studies.

- 1993. Ru: Biography of a Western Highlander. Boroko: National Research Institute.

Strathern Andrew, and Pamela J. Stewart. 1997. Ballads as Popular Performance Art in Papua New Guinea and Scotland. Centre for Pacific Studies Discussion Papers Series, 2. Townsville: James Cook University of North Queensland.

- 2000. Stories, Strength and Self-Narration. Adelaide: Crawford House Publications.

2005a. "Introduction." In Expressive Genres and Historical Change: Indonesia, Papua New Guinea and Taiwan, edited by Pamela J. Stewart and Andrew Strathern, 1-39. Anthropology and Cultural History in Asia and the Indo-Pacific. Hants: Ashgate Publishing.

2005b. "Melpa Songs and Ballads: Junctures of Sympathy and Desire in Mount Hagen, Papua New Guinea." In Expressive Genres and Historical Change: Indonesia, Papua New Guinea and Taiwan, edited by Pamela J. Stewart and Andrew Strathern, 201-33. Anthropology and Cultural History in Asia and the Indo-Pacific. Hants: Ashgate Publishing. 
Tedlock, Dennis. 1983. The Spoken Word and the Work of Interpretation. Philadelphia: University of Pennsylvania Press.

Vicedom, Georg F. 1937. "Ein neuentdecktes Volk in Neuguinea: Völkerkundliche Beobachtungen an der Bevölkerung des Hagen-Berges im ehemals deutschen Teil von Neuguinea." Archiv für Anthropologie 24: 11-44, 190-213.

Vicedom, Georg F., and Herbert Tischner. 1943. Die Mbowamb: Die Kultur der Hagenberg Stämme im östlichen Zentral-Neu Guinea. Dritter Band: Mythen und Erzählungen. Hamburg: Friedrichsen, de Gruyter.

1977. Myths and Legends from Mount Hagen. Translated by Andrew Strathern. Boroko: Institute of Papua New Guinea Studies. 